6. Shnabel N., Halabi S., Noor M. Overcoming competitive victimhood and facilitating forgiveness through re-categorization into a common victim or perpetrator identity // Journal of Experimental Social Psychology. 2013. Vol. 49. P. 867-877.

7. Гарькавець С. О. Конкурентна віктимність та ії психологічні механізми. // Теоретичні і прикладні проблеми психології : зб. наук. праць Східноукраїнського національного університету ім. В. Даля. Сєвєродонецьк: Вид-во СНУ ім. В. Даля, 2017. № 1 (42). С. 59-67.

8. Кононов І. Ф. Вплив війни на регіональну спільноту Донбасу // Тези доповідей та виступів учасників III Конгресу Соціологічної асоціації України «Нові нерівності - нові конфлікти: шляхи подолання» (12-13 жовтня 2017, м. Харків). Вид-во ХНУ ім. В. Н. Каразіна, 2017. C. $110-113$.

9. Гарькавец С. А., Яковенко С. И. Обида и ее инсталляция в контексте российско-украинских отношений // Электронный журнал / Фундаментальные исследования в практиках ведущих научных школ. 2014. № 4. URL:fund-issled-interm.esrae.ru/4-47 (дата звернення: 27.12.2017).

DOI https://doi.org/10.30525/978-9934-588-80-8-1.48

\title{
ПРОЯВИ ДЕВІАНТНОЇ АГРЕСІЇ У СПІЛКУВАННІ
}

\author{
Opoc O. Б. \\ кандидат соиіологічних наук, \\ дочент кафедри соиіології та соиіальної роботи \\ ДВНЗ «Ужгородський національний університет» \\ м. Ужгород, Украӥна \\ Спачинська C-E. I. \\ слухачка магістратури спеиіальності «Психологія» \\ Мукачівський державний університет \\ м. Мукачеве, Україна
}

Спілкування як процес встановлення та розвитку контактів між людьми, основний спосіб до розуміння іншої людини та засіб соціалізації, відіграє ключову роль у встановленні стосунків (дружніх, сімейних, ділових, партнерських). Проте сьогодні у часи суспільної кризи, пов'язаної в першу чергу із пандемією COVID-19, коли підвищений рівень стресу, посилення психопатологічної симптоматики, зниження можливості адекватно справлятися із стресом [1], спілкування все більше насичене деструктивними, девіантними проявами агресії, на 
противагу посиленню потреби у доброзичливому спілкуванні. Мета нашого дослідження ідентифікувати та спробувати пояснити девіантні прояви агресії у спілкуванні. Проблемі агресії у спілкуванні торкалися у своїх працях: А. Бандура, Р. Уолтерс, Л.Р. Хьюзман, Л. Ерон, Е. Руланн, Г. Сайкс, Д. Матца, С. Еніколопов, М. Цибульський, Г. Гіні, М. Кірпка, Н.Р. Крік, К.А. Додж, В. Бернер, К. Шмек, К. Галвег, Н. Гойер, С. Науман, А. Шік, І. Отт, Г. Шмід, Е. Кунче, С. Анлікер, Г. Боденманн.

Структура спілкування включає три сторони: комунікативну (обмін інформацією), інтерактивну (обмін діями), перцептивну (сприймання) [2]. Більшість дослідників визначають агресію як мотивоване нанесення шкоди. Д. Доллард та Міллер розглядали фрустрацію, особливо в ситуації неможливості подолати зовнішні перешкоди на шляху до отримання очікуваного задоволення [3]. Прояви девіантної агресії можуть бути спровоковані як інформацією, яку отримав суб'єкт, так і діями, проте прояви агресії в такому випадку скоріше за все носитимуть епізодичний i випадковий характер. Більш пролонгований у часі i передбачуваний агресивний сценарій спілкування передбачають комунікативні бар'єри у вигляді упереджених, завідомо агресивних схем сприйняття та хибної реконструкції партнера по спілкуванню (уявлення про його внутрішній світ, мотиви, мету). Проблему інтерпретації ситуації, яка провокує агресію розкрито в концепції соціального научіння А. Бандури. Якщо раніше особа потрапляла у ситуації, на які вона реагувала агресивно і це приносило успіх у вигляді підкріплення, то в подальшому навіть нейтральні за змістом подібні ситуації будуть сприйматися як негативні. Агресивні чи насильницькі дії завжди будуть пріоритетною формою реакції на подібні ситуації. Більше того, А. Бандура показує, що позитивно підкріплена дія кілька разів не потребує в подальшому детального аналізу, вона здійснюється автоматично [4]. Часто в процесі спілкування прояви агресії отримують так зване негативне підкріплення, коли агресія служить інструментом для припинення небажаної поведінки. Агресивні прояви у спілкуванні здатні припинити зауваження, критику, настанови, навіть прохання. У такому випадку агресор отримує негативне підкріплення і агресивно реагуватиме у подібних ситуаціях. Л.Р. Хюзмана [5] підтверджує, що соціальна поведінка особи контролюється тими програмами поведінки, які вона вивчила у ранньому віці. Саме спостереження за певними поведінковими зразками, (зокрема агресивними), $\epsilon$ основою для формування агресивних сценаріїв реагування при зіткненні із певними ситуаціями. Процес формування агресивних сценаріїв інтерпретації та реагування (скриптів) формується ще в дошкільному віці і багато в чому залежить від соціального середовища, в яке потрапила дитина. Звичайно, якщо дитина зростає в середовищі, де екстрапунітивні реакції, нецензурна лексика, лайка та образи $\epsilon$ нормальними i звичними 186 
атрибутами спілкування, то такий стиль спілкування буде притаманним i ій. При цьому, варто підкреслити, що агресія в більшості випадків виступає індикатором неблагополуччя. Сьогодні відмічається високий рівень агресії у соціальних мережах, так зване хейтерство, яке посилюється анонімністю комунікатора та відсутністю реакції (покарання) на агресивні прояви.

В психологічній літературі можемо побачити різні класифікації агресії. А.Басс виділяв ворожу (мета - нанесення шкоди) та інструментальну (мета - досягнення цілей іншого характеру) агресію, вербальну та невербальну, активну і пасивну. Фешбах виділяє експресивну, ворожу та інструментальну агресію. Ідентифікація девіантних проявів агресії в процесі спілкування - це часто складне завдання [6]. В процесі спілкування все ж принято говорити про вербальну агресію, яка може бути як активною так i пасивною. Остання найчастіше проявляється в обмеженні спілкування для свого партнера, сюди можемо віднести «бойкот», «гра у мовчанку», навмисне лаконічну реакцію «Так», «Ні», «Не знаю» на будь яке звернення. Вербальна активна агресія може проявлятися у тональності повідомлення, насмішках, відкритому кепкуванні, іронічних зауваженнях, нецензурній лайці та образливих прізвиськах. При цьому вербальна активна та пасивна агресія може слугувати як інструментом для досягнення певних цілей, так і мати на меті нанесення шкоди. Невербальна агресія в процесі спілкування може проявлятися у невербальних засобах комунікації: через жести (образливі, зневажливі, принижуючі), відповідні міміку, позу та навіть дії. Складність ідентифікації проявів агресії у спілкуванні пов'язана переважно з відмінностями у інтерпретації дій суб'єктами спілкування. Часто комунікатор може користуватися термінами ненормативної лексики через бідність словникового запасу, нерозуміння ситуації спілкування, високий рівень інфантильності, а реципієнт інтерпретує це як агресію.

Отже, девіантні прояви агресії у спілкуванні частішають у ситуації невизначеності, стресу та напруги і перешкоджають досягти головної мети спілкування. Здатність ідентифікувати їх та зрозуміти механізми виникнення може слугувати інструментом для психопрофілактики цього негативного явища у спілкуванні.

\section{Література:}

1. Бойко О.М., Медведева Т.И., Ениколопов С.Н., Воронцова О.Ю., Казьмина О.Ю. Психологическое состояние людей в период пандемии COVID-19 и мишени психологической работы // Психологические исследования. 2020. T. 13, № 70, C. 1. URL: http://psystudy.ru

2. Андреева Г.М. Социальная психология. Москва: Аспект Пресс. $1999,375 \mathrm{c}$. 
3. Dollard, John; Miller, Neal E.; Doob, Leonard W.; Mowrer, Orval H.; Sears, Robert R. Frustration and Aggression. New Haven, CT, US: Yale University Press, 1939.

4. Бандура А., Уолтерс Р. Подростковая агрессия. Изучение влияния воспитания и семейных отношений. Москва. Серия: Психология. XX век, 2000, 512 с.

5. Huesmann L.R., Moise J. Media violence; A demonstrated public threat to children// Harvard Mental Health Letter, 1996, vol. 12.

6. Хекхаузен Х. Мотивация и деятельность. М.: Смысл. 2003, 860 с.

DOI https://doi.org/10.30525/978-9934-588-80-8-1.49

\title{
ПСИХОЛОГІЧНІ ОСОБЛИВОСТІ ПРОЯВУ СИНДРОМУ ЕМОЦІЙНОГО ВИГОРАННЯ У ЮРИСТІВ
}

\author{
Шпак М. М. \\ доктор психологічних наук, доцент,
} професор кафедри психології розвитку та консультування

Тернопільський національний педагогічний університет імені Володимира Гнатюка

Ороновська О. М.

магістрантка кафедри психологї̈ розвитку та консультування (спеціальність «Психологія»)

Тернопільський національний педагогічний університет імені Володимира Гнатюка м. Тернопіль, Украӥна

Професійна діяльність юриста вимагає наявності низки професійно значущих та особистісних якостей, які б забезпечували психологічну готовність фахівця до роботи в напружених, емоціогенних умовах, стресових ситуаціях, які можуть призвести до синдрому «емоційного вигорання».

Проблема емоційного вигорання була предметом дослідження багатьох вітчизняних (В. Бойко, I. Ващенко, Н. Водоп'янова, Л. Карамушка, М. Смульсон, Н. Чепелєва, Л. Юр'єва та ін.) та зарубіжних (Дж. Грінберг, А. Ленгле, К. Маслач, Дж. Моллі, Дж Сторлі, Г. Фрейденбергер та ін.) психологів. У працях цих учених розкрито зміст, соціально-психологічні чинники та ознаки прояву емоційного вигорання особистості. Однак вивченню особливостей прояву синдрому емоційного вигорання у юристів присвячено невелику 